\title{
Landslide damage along Araniko highway and Pasang Lhamu highway and regional assessment of landslide hazard related to the Gorkha, Nepal earthquake of 25 April 2015
}

\author{
Chong Xu ${ }^{1 *}$, Yingying Tian ${ }^{1}$, Bengang Zhou ${ }^{1}$, Hongliu Ran ${ }^{1}$ and Gaohu Lyu ${ }^{2}$
}

\begin{abstract}
Background: The Gorkha, Nepal Mw 7.8 earthquake of 25 April 2015 triggered a large number of coseismic landslides in a broad area. Two highways, Araniko Highway and Pasang Lhamu Highway, that connect Tibet of China and Nepal, were affected seriously by these landslides. The purpose of this study was to investigate the landslide damage along the two highways, construct a detailed and complete inventory of coseismic landslides in the 5-km buffer area of the Araniko Highway, and perform a regional assessment of landslide hazard in the affected area.

Findings: Based on visual interpretation of high-resolution satellite images, field investigations, and GIS technology, we investigated the coseismic landslides along the Araniko Highway and Pasang Lhamu Highway. A detailed pointbased inventory of coseismic landslides was constructed and spatial distributions of the landslides were analyzed. Correlations between the landslides and five controlling factors, i.e. elevation, slope angle, slope aspect, lithology, and seismic intensity, were illustrated statistically which permitted to assess landslides hazard in a larger rectangle area.

Conclusions: We examined the coseismic landslides of the 2015 Gorkha earthquake that blocked or damaged the Araniko Highway $(117.3 \mathrm{~km})$ and Pasang Lhamu Highway $(139.3 \mathrm{~km})$ in Nepal. Results show 35 coseismic landslides damaged the Araniko Highway along a total length $1,415 \mathrm{~m}$. The total volume of them was estimated to be 0.37 million $\mathrm{m}^{3}$. We delineated 89 coseismic landslides that damaged the Pasang Lhamu Highway, where the total length of the damaged or buried roads is about 2,842 $\mathrm{m}$ and the total volume of the 89 landslides is about $1.47 \mathrm{million}^{3}$. In the 5-km buffer area along the Araniko Highway, we mapped 3,005 landslides caused by the Gorkha earthquake. The landslide number density of the study area is $2.925 \mathrm{~km}^{-2}$. The places with elevations 2,000-2,500 m have the highest landslide concentration. Landslide number density values increase with the slope angle. The slope aspects $E$ and SE correspond to the highest concentrations of coseismic landslides. The underlying bedrock of Precambrian rocks-1 (Pc1) registered the largest landslide number density. The area of seismic intensity IX has a much higher LND value than that of the intensity VIII. We used the weigh index method to perform landslide hazard assessment in the 5-km buffer area on either side of the highway, which shows a success ratio of $85.9 \%$. This method has been applied to a larger area mainly encompassing Rasuwa and Sindhupalchok counties of Nepal.
\end{abstract}

Keywords: Gorkha earthquake, Coseismic landslides, Field investigation, Visual interpretation, Landslide hazard assessment

\footnotetext{
* Correspondence: xuchong@ies.ac.cn

${ }^{1}$ Key Laboratory of Active Tectonics and Volcano, Institute of Geology, China

Earthquake Administration, 1\# Huayanli, Chaoyang District, PO Box 9803,

Beijing 100029, China

Full list of author information is available at the end of the article
} 


\section{Introduction}

The 25 April 2015 Gorkha, Nepal Mw 7.8 earthquake caused more than 8,800 fatalities and enormous economic losses. It also triggered a large number of coseismic landslides, mainly shallow and disrupted landslides and a few deep-seated landslides, some of which buried villages, roads, and valleys (Hashash et al. 2015; Moss et al. 2015; Dahal 2016; Gnyawali et al. 2016; Martha et al. 2016; Wang et al. 2016; Xu et al. 2016a). The affected areas include Central Nepal and Gyirong and Nielamu counties of southern Tibet, China. The coseismic landslides seriously damaged two highways, Pasang Lhamu Highway and Araniko Highway, connecting China and Nepal. After the event, several research teams carried out field investigations of seismic damages and earthquake-triggered landslides (Collins and Jibson 2015;
Hashash et al. 2015; Sun and Yan 2015; Kargel et al. 2016; Lacroix 2016; Sharma et al. 2016). Until now, however, little work focuses on the landslides that damaged these two highways. Although the materials of the coseismic landslides blocking the two main roads have been cleaned up in time, some new landslides were triggered by aftershocks or strong rainfalls, resulting in further damage. Therefore, identifying the landslides destroying the roads and assessment of landslide hazard is very important for prevention and mitigation of future geologic hazard around these two roads. In this work, we firstly identified the coseismic landslides that destroyed the Lhamu Highway and Araniko Highway using field investigation and visual interpretation of satellite images. Then we constructed a detailed inventory map containing 3,005 individual coseismic landslides in

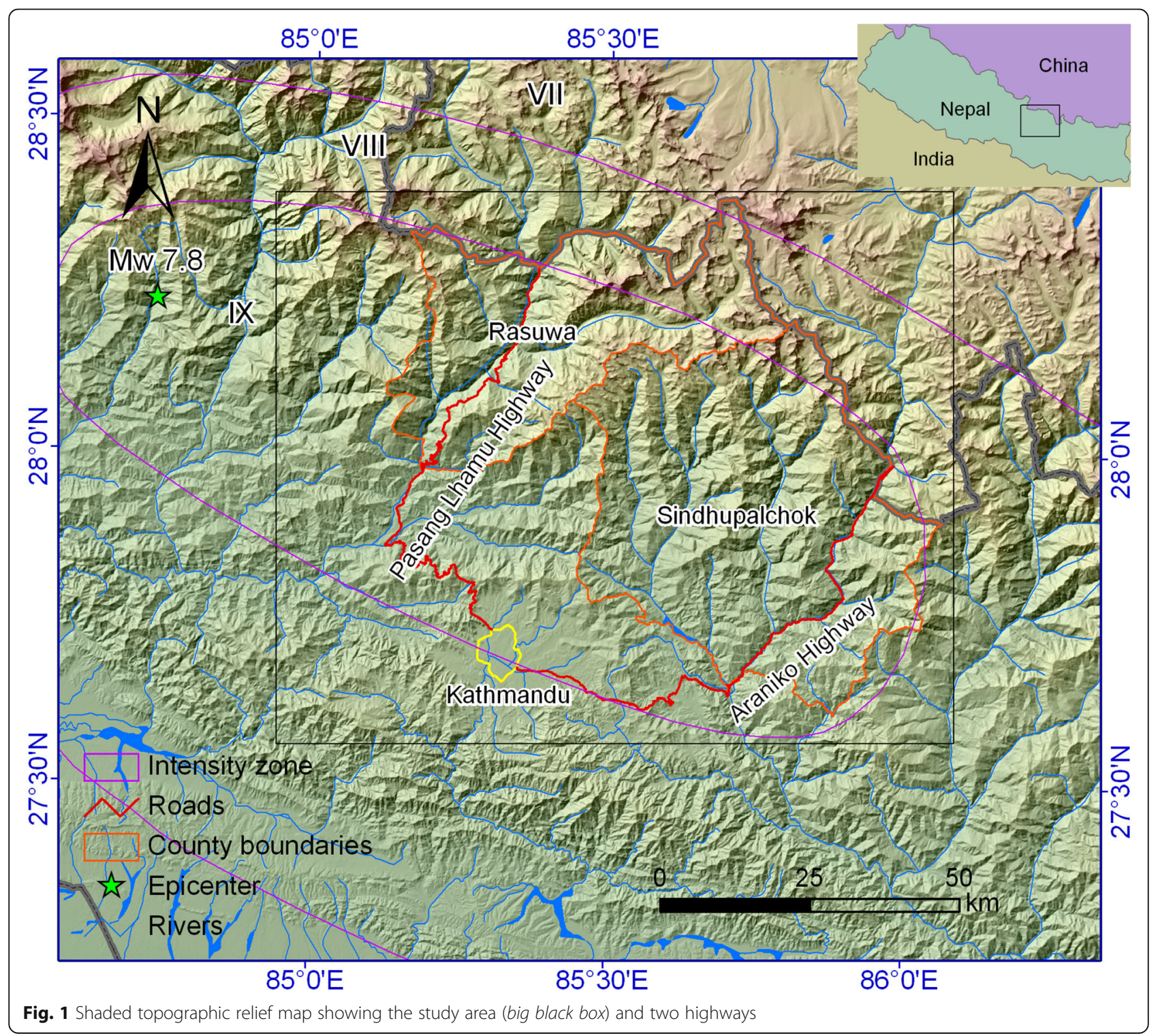


the buffer area of $5 \mathrm{~km}$ to the Araniko Highway. Next, correlations between the 3,005 landslides and five landslide controlling factors were analyzed. Finally, we performed landslide hazard assessment for a larger area affected by the Gorkha earthquake using the weigh index (WI) method.

\section{Data and methods}

\section{The study area}

Despite its large magnitude, the Gorkha earthquake did not produce visible ruptures on the surface, which was confined to the subsurface at depths 10-15 km (Angster et al. 2015;
Avouac et al. 2015; Hashash et al. 2015; Parameswaran et al. 2015; Duputel et al. 2016; Elliott et al. 2016). The earthquake-affected area is mainly in the east to the epicenter $\left(28.23^{\circ} \mathrm{N}, 84.731^{\circ} \mathrm{E}\right)$, likely associated with the eastward rupturing directivity (Wang and Fialko 2015; Koketsu et al. 2016), from which we selected is a rectangular area as the study area, which has a length of $113 \mathrm{~km}$ in eastwest direction and width of $92 \mathrm{~km}$ in north-south direction (Fig. 1), covering 10,396 $\mathrm{km}^{2}$. From north to south, the elevation of the study area generally declines from 7,975 $\mathrm{m}$ to $387 \mathrm{~m}$, i.e. more than 7,500 m elevation drop in an about $100 \mathrm{~km}$-wide zone. The

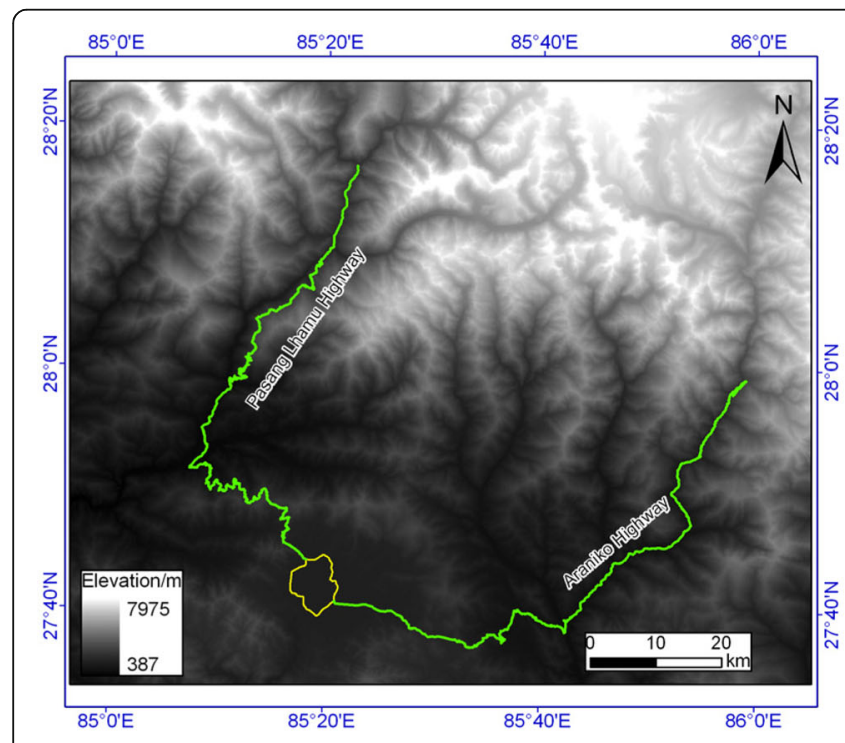

(a)

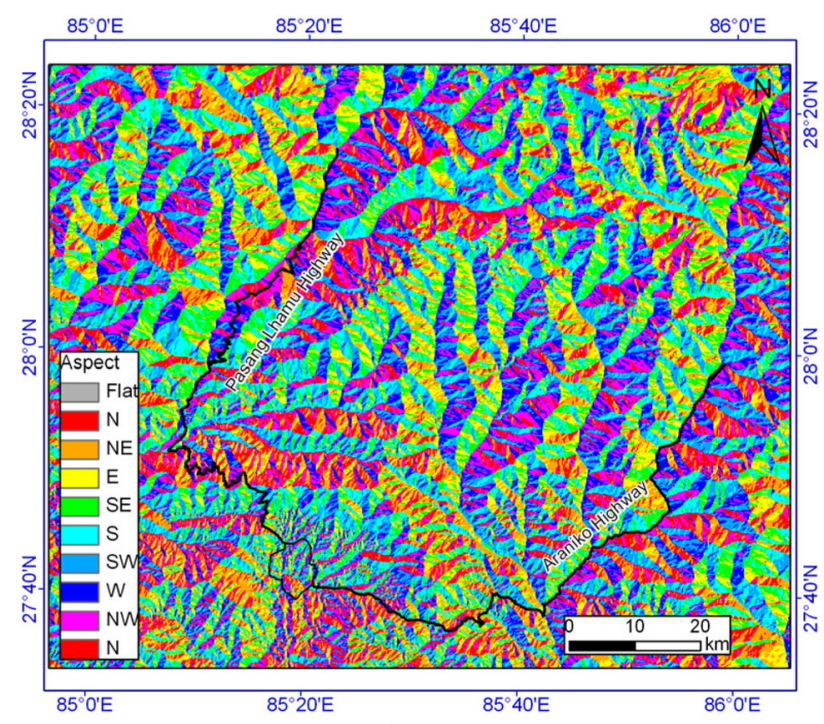

(c)

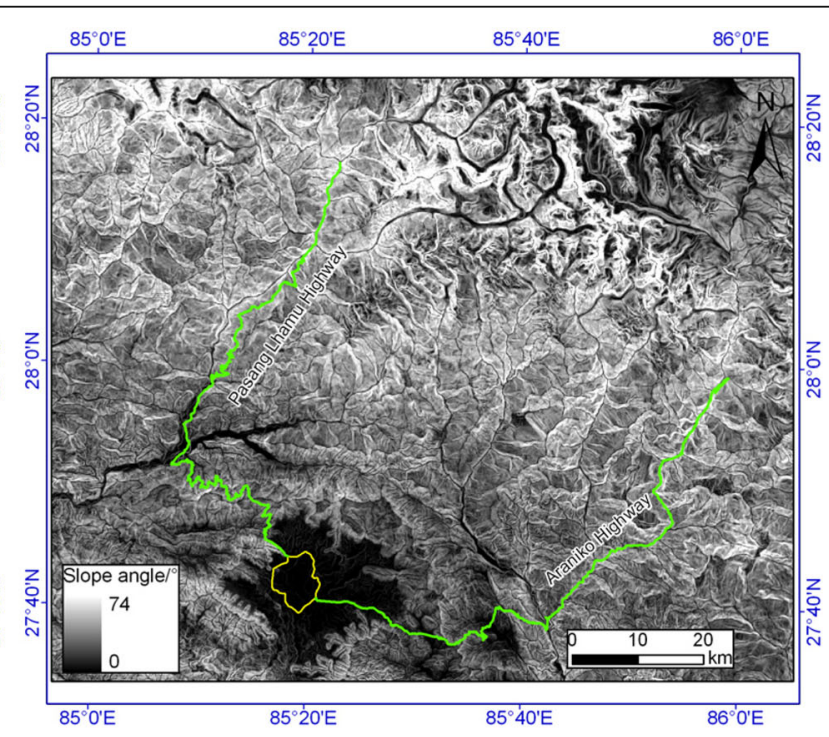

(b)

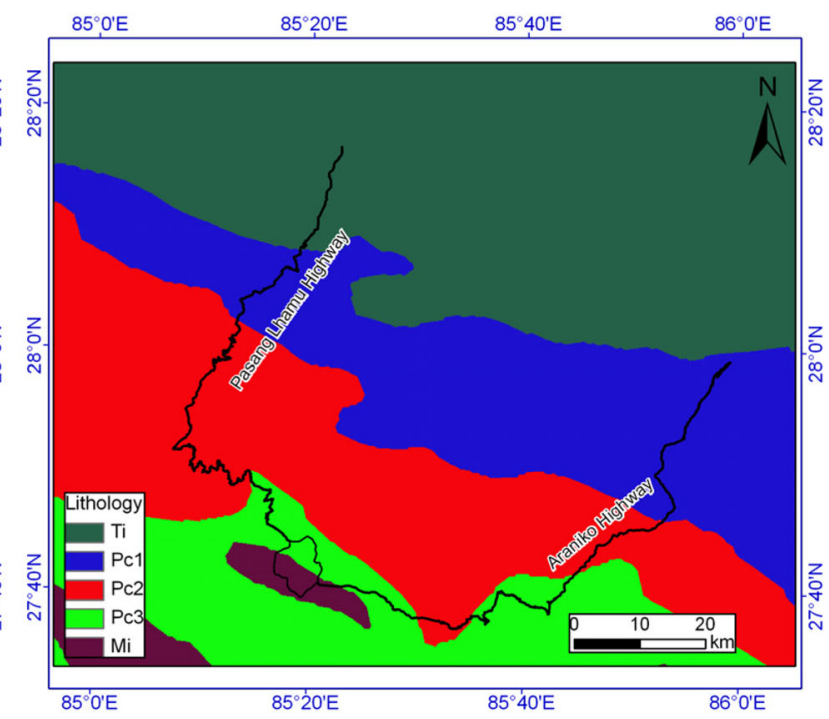

(d)

Fig. 2 Maps showing controlling factors of coseismic landslides of the study area. a Elevation. b Slope angle. c Aspect. d Lithology (sources are mentioned in the text) 
area encompasses the Rasuwa and Sindhupalchok counties of Nepal (Fig. 1). The Araniko Highway passes through Sindhupalchok county and the Pasang Lhamu Highway passes through Rasuwa county, respectively. Based on the seismic intensity map released by the China Earthquake Administration (www.cea.gov.cn), most of the study area lies in the IX intensity zone, and part in VIII and VII intensity zones (Fig. 1).

\section{Data}

The satellite images for landslide interpretation are from the Google Earth (GE) platform. After the earthquake occurred, several organizations have implemented specialized tasks to obtain post-earthquake satellite images. Some of the images with very high resolution ( $1 \mathrm{~m}$ or better) are available on the Google Earth platform. In addition, pre-earthquake images with high quality and resolution in the area are also available on the GE platform. These images allow researchers to map co-seismic landslides conveniently and accurately. The regional DEM for analyzing correlations between topography and coseismic landslides were derived from SRTM DEM in 3-arc-second resolution (Fig. 2a). The slope angle map (Fig. 2b) and aspect map (Fig. 2c) were derived from the regional DEM on the GIS platform. The geologic map (Fig. 2d) of the study area was clipped and revised from "World Geologic Maps" on the USGS Website (www.usgs.gov).

\section{Methods}

\section{Landslide identification}

In this study, we used two methods to identify landslides, i.e. visual interpretation of pre- and postearthquake satellite images and field investigation. Computer screen-based visual interpretation of satellite images is the most widely used method for earthquaketriggered landslide mapping which permits to prepare high-quality landslide inventories (Xu 2015). As a supplement and verification of results from visual interpretation, we carried out several days of field investigation mainly along the Pasang Lhamu Highway and Araniko Highway.

\section{Spatial distribution and hazard assessment of landslides}

The Gorkha, Nepal earthquake affected a very large area about tens of thousands of square kilometers. Immediately after the quake, it was difficult to construct a detailed and complete landslide inventory throughout the affected area. Fortunately, spatial distribution of the partial affected area can represent the overall spatial patterns of landslides under some conditions (Lee et al. 2008; Xu et al. 2013a). Therefore, we selected a 5-km buffer area on either side of the Araniko Highway to construct a detailed landslide inventory. Although we prepared a polygon-based inventory of landslides that directly damaged Araniko Highway and Pasang Lhamu Highway, we chose point-based inventory of coseismic landslides and landslide number density (LND, defined as the number of landslides per square kilometers (Xu et al. 2013b) to conduct analysis of the spatial distribution and hazard assessment of landslides. The reasons include: (1) The precise source area of a landslide is very difficult to be distinguished from the whole landslide area because the boundaries of the source area, movement area, and accumulation area of the landslide are usually in the subsurface, thus cannot be exactly delineated, which perhaps reduce the objectiveness of landslides hazard assessment. (2) Preparation of a point-based landslide inventory is relatively time-saving, permitting to carry out a quick regional assessment of earthquaketriggered landslides. Five controlling factors, including elevation, slope angle, slope aspect, lithology, and seismic intensity were taken into account for a statistical analysis. Currently, many statistical methods are available for landslide hazard assessment (Xu et al. 2012; Feng et al. 2016; Pathak 2016; Tsangaratos and Ilia 2016), among which the

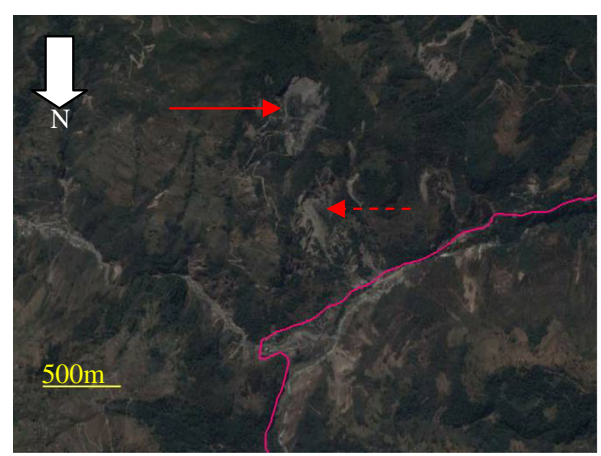

(a)

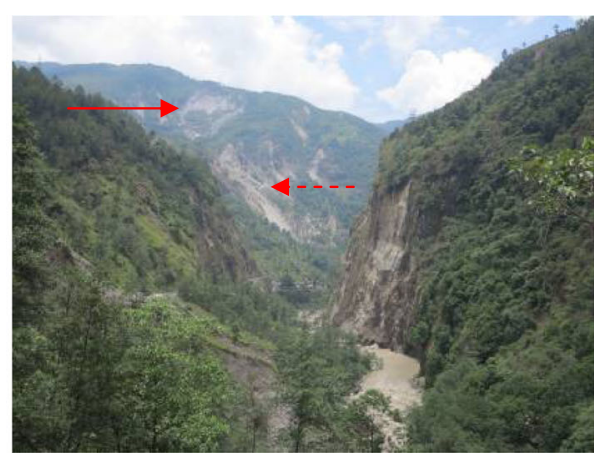

(b)

Fig. 3 Coseismic landslides at the Araniko Highway. a Satellite image of 4 May 2015. b Field photo of 14 June 2015 (by Chong Xu, view to south). The solid and dotted arrows in (a) and (b) show the same places, respectively 


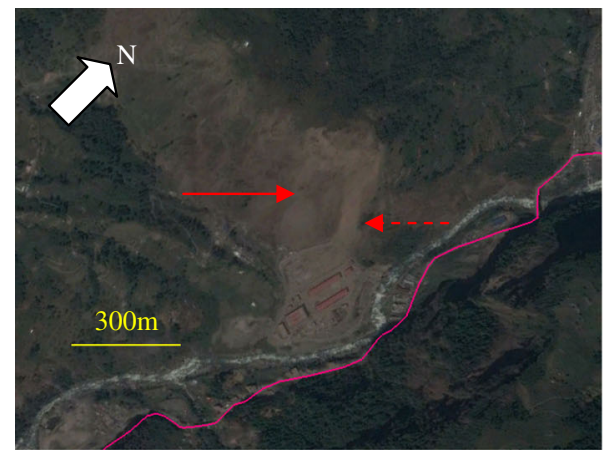

(a)

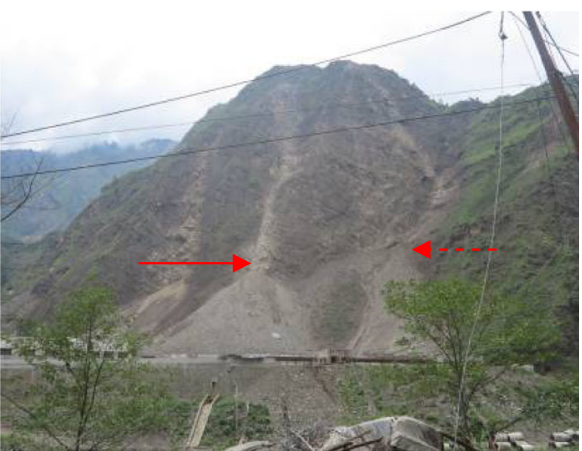

(b)

Fig. 4 Rockfalls on the upper slope of an inspection station of Nepal. a Satellite image of 4 May 2015. b Field photo of 14 June 2015 (by Chong Xu, view to northwest). The solid and dotted arrows in (a) and (b) indicate the same places, respectively

bivariate statistical analysis method has been widely used in various areas because it is time-saving and does not need complex calculations (Xu et al. 2013b). In this study, a weight index (WI) model was employed to perform landslide susceptibility mapping in the $5-\mathrm{km}$ buffer area aforementioned. This WI method is based on a bivariate statistical analysis based on calculating landslide number density (LND). In this method, the weigh value of each factor class is defined as the natural logarithm of the LND in the class divided by the LND of the whole area (Sarkar et al. 2008; Yalcin 2008; Xu et al. 2013b):

$$
\begin{aligned}
\mathrm{WI}_{i} & =\ln \left(\mathrm{LND}_{\mathrm{i}} / \mathrm{LND}\right) \\
& =\ln \left(\left(\mathrm{LN}_{\mathrm{i}} / \text { Area }_{\mathrm{i}}\right) /(\mathrm{LN} / \text { Area })\right)
\end{aligned}
$$

where $\mathrm{WI}_{i}$ is the weight of the factor-class $i, \mathrm{LND}_{i}$ is the landslide number intensity within the area of the $i$ th factor class, and LND is the landslide number intensity in the whole area. In this study, the value of LND is 3,005/ $1,027.4 \mathrm{~km}^{2}=2.925 \mathrm{~km}^{-2}$.

\section{Findings, results and analysis}

Landslides on satellite images

In this section, we present several groups of comparisons of satellite images and field photos of coseismic landslides to illustrate the excellent capacity of detecting coseismic landslides on high-resolution satellite images. The satellite images used in this study are from the GE platform collected in early May, 2015. The red solid arrow on Fig. 3 shows a coherent landslide $\left(27.87^{\circ} \mathrm{N}, 85.911^{\circ} \mathrm{E}\right)$ with clear exposed bedrocks in the landslide source area and partly damaged vegetation stayed at its deposit area. The red dotted line defines several shallow, disrupted landslides along the Araniko Highway road. Due to the high resolution and quality of the satellite image, the locations and boundaries of the landslides can be mapped correctly and conveniently on the ortho images.

Figure 4 shows two rockfalls $\left(27.927^{\circ} \mathrm{N}, 85.932^{\circ} \mathrm{E}\right)$ occurred on the upper slope at an inspection station of Nepal, which originated from nearby the ridge of the reverse slope and accumulated into two conical heaps with two narrow runout paths. The broken accumulate

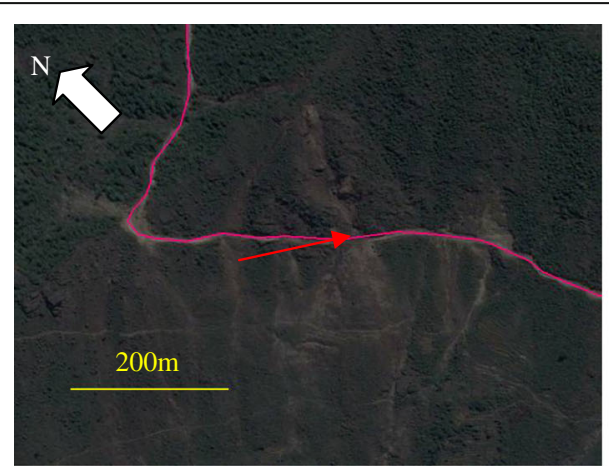

(a)

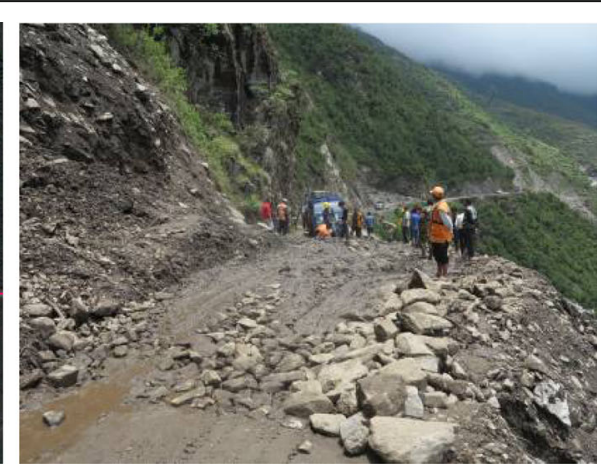

(b)

Fig. 5 A series of shallow, disrupted landslides blocking the Pasang Lhamu Highway. a Satellite image of 3 May 2015 . b Field photo of 15 June 2015 (by Chong Xu, view to southeast) showing the road was blocked by a secondary landslide caused by a heavy rainfall. The red solid arrow in (a) shows the location of field photo in (b) 


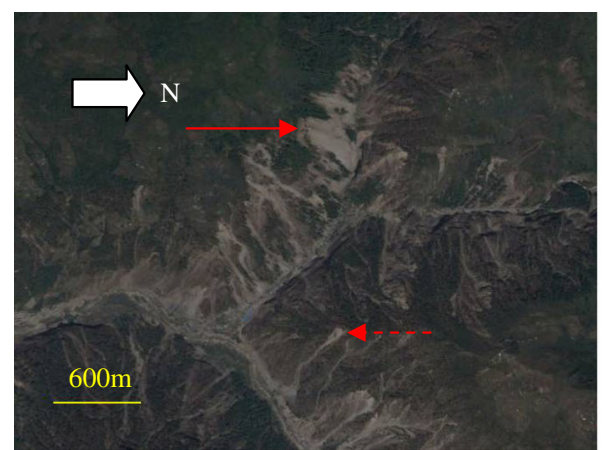

(a)

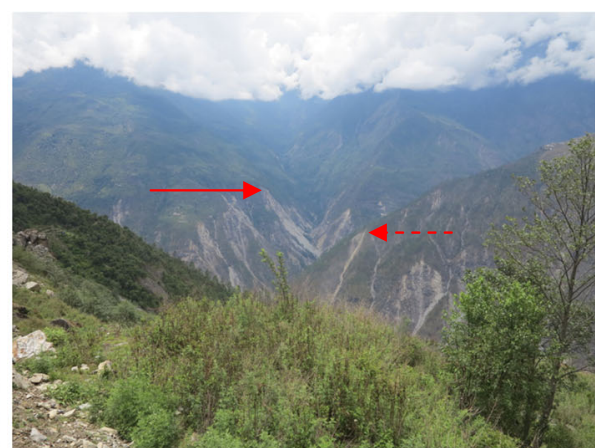

(b)

Fig. 6 An area characterized by high density of coseismic landslides. a Satellite image taken on 3 May 2015. b Field photo taken on 15 June 2015 (by Chong Xu, view to west). The solid and dotted arrows denote the same places, respectively

materials are dangerous for the structures on the toe of the slope. Despite different expressions of the rockfalls on the image and field photos due to the image stretching caused by steep topography, the rockfalls can be easily identified on the satellite image with the aid of field investigations. They have short runout distances on the image, whereas the actual runout distances of them are likely longer. This is because the slope of the rockfalls occurrence is almost vertical. Small rockfalls or falling stones are more susceptible than large deep-seated landslides on such a reverse slope.

After the main shock, a series of aftershocks and rainfalls struck the affected area and caused more landslides. For example, the satellite image of 3 May 2015 (Fig. 5a) shows quite a few shallow, disrupted landslides (located at $\left.28.064^{\circ} \mathrm{N}, 85.225^{\circ} \mathrm{W}\right)$ that occurred in weathering layers

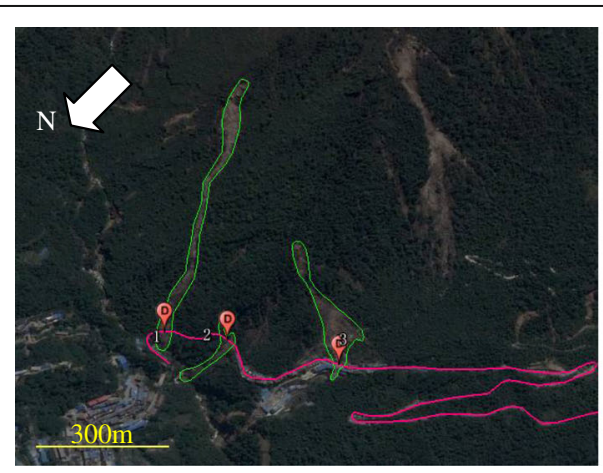

(a)

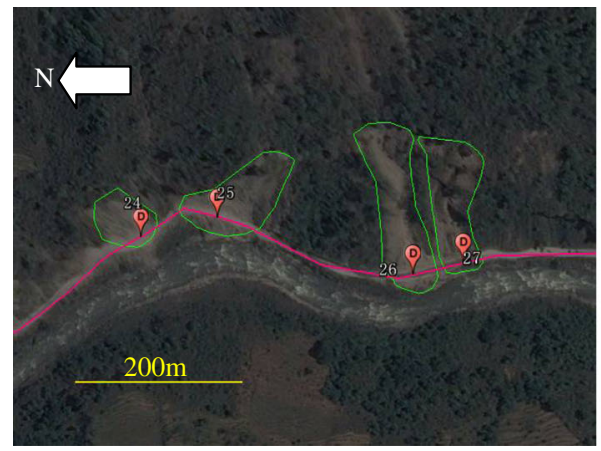

(c)

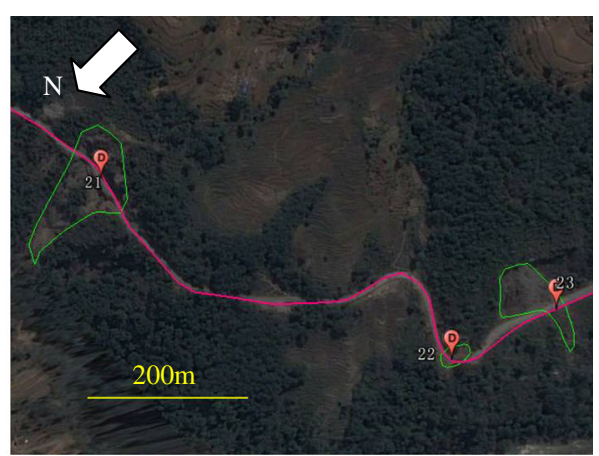

(b)

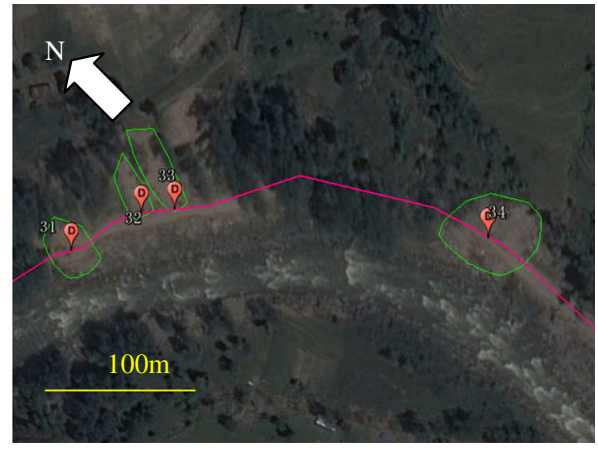

(d)

Fig. 7 Damaged sites along Araniko Highway by coseismic landslides have been seen on satellite images. The detailed information of the landslides and associated damages on the road is listed in Table 1. a the No. 1, 2, and 3 landslides, (b) the No. 21, 22, and 23 landslides, (c) the No. 24, 25, 26, and 27 landslides, and (d) the No. 31, 32, 33, and 34 landslides along Araniko Highway. All the satellite images were acquired on 4 May, 2015 
and blocked the Pasang Lhamu Highway. Fig. 5b shows the road was blocked by a secondary landslide caused by a heavy rainfall in the area. Information from local residents suggests that the landslide accumulation material that blocked the road was not triggered by the main shock, but by a strong rainfall a few days before. All the landslide materials related to the main shock and subsequent triggers blocking the roads have been cleared up or were being cleared away in time to keep the traffic flowing.

The satellite image (Fig. 6a) shows an area with high density of coseismic landslides, dominated by shallow, disrupted landslides. The red solid arrows wherein

Table 1 Information of damage along the Araniko Highway and associated coseismic landslides

\begin{tabular}{|c|c|c|c|c|c|}
\hline No. & Longitude $\left(^{\circ}\right)$ & Latitude $\left(^{\circ}\right)$ & Length of road damaged $(\mathrm{m})$ & Area $\left(m^{2}\right)$ & Estimated volume $\left(\mathrm{m}^{3}\right)$ \\
\hline 1 & 85.98343 & 27.9868 & 45 & 29131 & 50000 \\
\hline 2 & 85.98196 & 27.98562 & 52 & 6180 & 12000 \\
\hline 3 & 85.9791 & 27.98369 & 35 & 22953 & 60000 \\
\hline 4 & 85.96235 & 27.97215 & 16 & 3648 & 6000 \\
\hline 5 & 85.96186 & 27.97166 & 27 & 3756 & 7000 \\
\hline 6 & 85.96482 & 27.96926 & 29 & 8383 & 20000 \\
\hline 7 & 85.96511 & 27.96912 & 30 & ditto & ditto \\
\hline 8 & 85.95799 & 27.96591 & 10 & 435 & 400 \\
\hline 9 & 85.93064 & 27.91744 & 156 & 31816 & 20000 \\
\hline 10 & 85.92627 & 27.91352 & 19 & 4233 & 8000 \\
\hline 11 & 85.9227 & 27.90877 & 5 & 972 & 1000 \\
\hline 12 & 85.92241 & 27.90828 & 27 & 2271 & 3000 \\
\hline 13 & 85.9222 & 27.9079 & 33 & 2630 & 4000 \\
\hline 14 & 85.91496 & 27.8927 & 10 & 15890 & 30000 \\
\hline 15 & 85.91307 & 27.88253 & 30 & 1739 & 2000 \\
\hline 16 & 85.90599 & 27.87934 & 46 & 12025 & 30000 \\
\hline 17 & 85.90493 & 27.87892 & 12 & 268 & 200 \\
\hline 18 & 85.90185 & 27.87782 & 115 & 6224 & 10000 \\
\hline 19 & 85.89957 & 27.87686 & 49 & 4245 & 6000 \\
\hline 20 & 85.89595 & 27.87602 & 15 & 303 & 200 \\
\hline 21 & 85.88781 & 27.87385 & 95 & 9237 & 20000 \\
\hline 22 & 85.88341 & 27.87226 & 25 & 608 & 500 \\
\hline 23 & 85.88309 & 27.87113 & 20 & 3583 & 5000 \\
\hline 24 & 85.88062 & 27.85115 & 43 & 3805 & 5000 \\
\hline 25 & 85.88092 & 27.85034 & 94 & 7461 & 15000 \\
\hline 26 & 85.88045 & 27.84828 & 54 & 9367 & 20000 \\
\hline 27 & 85.88063 & 27.84779 & 42 & 7061 & 15000 \\
\hline 28 & 85.87291 & 27.82729 & 57 & 3399 & 5000 \\
\hline 29 & 85.87352 & 27.82707 & 43 & 3094 & 5000 \\
\hline 30 & 85.89329 & 27.8036 & 15 & 1250 & 1500 \\
\hline 31 & 85.89425 & 27.80022 & 30 & 949 & 1000 \\
\hline 32 & 85.89475 & 27.80006 & 13 & 522 & 300 \\
\hline 33 & 85.89492 & 27.79994 & 7 & 937 & 1000 \\
\hline 34 & 85.89613 & 27.7986 & 52 & 1971 & 2500 \\
\hline 35 & 85.88417 & 27.77117 & 1 & 628 & 500 \\
\hline 36 & 85.77906 & 27.73006 & 63 & 3778 & 5000 \\
\hline Total & & & 1,415 & 214,751 & 372,100 \\
\hline
\end{tabular}

No. 6 and No. 7 landslide-damaged sections were caused by one landslide 
Table 2 Information of damaged along the Pasang Lhamu Highway and associated coseismic landslides

\begin{tabular}{|c|c|c|c|c|c|}
\hline No. & $\begin{array}{l}\text { Longitude } \\
\left({ }^{\circ}\right)\end{array}$ & $\begin{array}{l}\text { Latitude } \\
\left({ }^{\circ}\right)\end{array}$ & $\begin{array}{l}\text { Length of road } \\
\text { damaged }(\mathrm{m})\end{array}$ & $\begin{array}{l}\text { Area } \\
\left(\mathrm{m}^{2}\right)\end{array}$ & $\begin{array}{l}\text { Estimated } \\
\text { volume }\left(\mathrm{m}^{3}\right)\end{array}$ \\
\hline$\overline{1}$ & 85.24384 & 27.82563 & 12 & 166 & 100 \\
\hline 2 & 85.23569 & 27.82943 & 14 & 613 & 500 \\
\hline 3 & 85.20104 & 27.83575 & 14 & 275 & 200 \\
\hline 4 & 85.13849 & 27.8637 & 17 & 628 & 500 \\
\hline 5 & 85.18591 & 27.98131 & 18 & 311 & 200 \\
\hline 6 & 85.1884 & 27.98278 & 14 & 197 & 100 \\
\hline 7 & 85.18866 & 27.98288 & 16 & 209 & 100 \\
\hline 8 & 85.18777 & 27.9828 & 50 & 1144 & 1200 \\
\hline 9 & 85.21029 & 28.00465 & 16 & 336 & 300 \\
\hline 10 & 85.2181 & 28.01873 & 9 & 177 & 100 \\
\hline 11 & 85.22025 & 28.02089 & 21 & 553 & 400 \\
\hline 12 & 85.22087 & 28.02175 & 28 & 2766 & 4000 \\
\hline 13 & 85.22311 & 28.02457 & 40 & 32568 & 80000 \\
\hline 14 & 85.22349 & 28.02528 & 48 & 17673 & 50000 \\
\hline 15 & 85.22334 & 28.02617 & 39 & 10247 & 20000 \\
\hline 16 & 85.22309 & 28.02716 & 45 & 9266 & 20000 \\
\hline 17 & 85.22299 & 28.02766 & 18 & 10071 & 20000 \\
\hline 18 & 85.21933 & 28.0394 & 14 & 199 & 100 \\
\hline 19 & 85.22441 & 28.04657 & 14 & 227 & 100 \\
\hline 20 & 85.22547 & 28.04732 & 7 & 171 & 100 \\
\hline 21 & 85.22722 & 28.04826 & 24 & 805 & 800 \\
\hline 22 & 85.22892 & 28.05021 & 22 & 279 & 200 \\
\hline 23 & 85.22869 & 28.05054 & 14 & 103 & 100 \\
\hline 24 & 85.22923 & 28.05373 & 5 & 271 & 200 \\
\hline 25 & 85.22867 & 28.05858 & 19 & 11564 & 5000 \\
\hline 26 & 85.22811 & 28.06002 & 53 & 3790 & 5000 \\
\hline 27 & 85.22798 & 28.061 & 67 & 7609 & 15000 \\
\hline 28 & 85.22674 & 28.0633 & 57 & 5222 & 10000 \\
\hline 29 & 85.22643 & 28.06371 & 19 & 1815 & 2000 \\
\hline 30 & 85.22562 & 28.0644 & 28 & 9168 & 20000 \\
\hline 31 & 85.22542 & 28.06454 & 15 & 3018 & 4000 \\
\hline 32 & 85.22515 & 28.06481 & 14 & 525 & 300 \\
\hline 33 & 85.22494 & 28.06501 & 21 & 2679 & 3000 \\
\hline 34 & 85.22447 & 28.06545 & 31 & 5012 & 5000 \\
\hline 35 & 85.22374 & 28.06637 & 36 & 3662 & 5000 \\
\hline 36 & 85.22535 & 28.06689 & 25 & 2876 & 4000 \\
\hline 37 & 85.22884 & 28.06806 & 59 & 11267 & 20000 \\
\hline 38 & 85.23007 & 28.06827 & 99 & 20358 & 60000 \\
\hline 39 & 85.23904 & 28.07238 & 209 & 54607 & 200000 \\
\hline 40 & 85.25552 & 28.0772 & 16 & 920 & 800 \\
\hline 41 & 85.2558 & 28.07737 & 11 & 152 & 100 \\
\hline 42 & 85.25023 & 28.07813 & 13 & 500 & 300 \\
\hline 43 & 85.277 & 28.09335 & 18 & 241 & 100 \\
\hline
\end{tabular}

Table 2 Information of damaged along the Pasang Lhamu Highway and associated coseismic landslides (Continued)

\begin{tabular}{|c|c|c|c|c|c|}
\hline$\overline{44}$ & 85.27853 & 28.09454 & 15 & 169 & 100 \\
\hline 45 & 85.2867 & 28.10178 & 9 & 95 & 100 \\
\hline 46 & 85.28784 & 28.104 & 7 & 109 & 40000 \\
\hline 47 & 85.2877 & 28.10459 & 104 & 15961 & 3000 \\
\hline 48 & 85.28754 & 28.1055 & 30 & 2082 & 3000 \\
\hline 49 & 85.28715 & 28.10675 & 14 & 577 & 500 \\
\hline 50 & 85.31217 & 28.10857 & 19 & 1711 & 2000 \\
\hline 51 & 85.31202 & 28.10873 & 22 & 1306 & 1500 \\
\hline 52 & 85.31183 & 28.11008 & 60 & 10024 & 250000 \\
\hline 53 & 85.31135 & 28.11061 & 49 & 4482 & 8000 \\
\hline 54 & 85.31117 & 28.11098 & 17 & 1550 & 2000 \\
\hline 55 & 85.29239 & 28.11159 & 24 & 555 & 500 \\
\hline 56 & 85.31072 & 28.11175 & 41 & 3888 & 6000 \\
\hline 57 & 85.31043 & 28.11217 & 55 & 7463 & 15000 \\
\hline 58 & 85.29454 & 28.11298 & 6 & 168 & 100 \\
\hline 59 & 85.30909 & 28.11914 & 11 & 117 & 100 \\
\hline 60 & 85.30815 & 28.12234 & 14 & 5918 & 12000 \\
\hline 61 & 85.30685 & 28.12406 & 4 & 357 & 300 \\
\hline 62 & 85.34242 & 28.17233 & 25 & 957 & 1000 \\
\hline 63 & 85.34248 & 28.17269 & 31 & 4223 & 8000 \\
\hline 64 & 85.34254 & 28.17314 & 14 & 1996 & 2000 \\
\hline 65 & 85.3426 & 28.17358 & 63 & 21402 & 60000 \\
\hline 66 & 85.34237 & 28.178 & 18 & 1374 & 2000 \\
\hline 67 & 85.34225 & 28.17896 & 11 & 695 & 800 \\
\hline 68 & 85.3439 & 28.18229 & 14 & 197 & 100 \\
\hline 69 & 85.34455 & 28.18387 & 17 & 4005 & 6000 \\
\hline 70 & 85.34617 & 28.18621 & 30 & 33718 & 100000 \\
\hline 71 & 85.34634 & 28.18678 & 57 & 32800 & 100000 \\
\hline 72 & 85.34741 & 28.18903 & 16 & 565 & 500 \\
\hline 73 & 85.34761 & 28.18932 & 24 & 8214 & 10000 \\
\hline 74 & 85.34883 & 28.19127 & 59 & 18536 & 30000 \\
\hline 75 & 85.34972 & 28.19332 & 14 & 445 & 300 \\
\hline 76 & 85.35092 & 28.19643 & 19 & 398 & 300 \\
\hline 77 & 85.35147 & 28.19703 & 41 & 4677 & 80000 \\
\hline 78 & 85.35182 & 28.19742 & 27 & 3538 & 5000 \\
\hline 79 & 85.35224 & 28.19803 & 13 & 1716 & 1000 \\
\hline 80 & 85.35285 & 28.19931 & 19 & 3032 & 3000 \\
\hline 81 & 85.35292 & 28.19967 & 12 & 1805 & 1000 \\
\hline 82 & 85.35304 & 28.20057 & 43 & 2852 & 5000 \\
\hline 83 & 85.35425 & 28.20403 & 41 & 1693 & 2500 \\
\hline 84 & 85.35507 & 28.20837 & 38 & 4976 & 10000 \\
\hline 85 & 85.35804 & 28.2197 & 102 & 13969 & 40000 \\
\hline 86 & 85.36041 & 28.22164 & 19 & 3995 & 5000 \\
\hline 87 & 85.36106 & 28.22261 & 107 & 14279 & 30000 \\
\hline
\end{tabular}


Table 2 Information of damaged along the Pasang Lhamu Highway and associated coseismic landslides (Continued)

\begin{tabular}{|c|c|c|c|c|c|}
\hline$\overline{88}$ & 85.36698 & 28.25649 & 44 & 2549 & 4000 \\
\hline 89 & 85.37802 & 28.27514 & 92 & 21169 & 60000 \\
\hline \multicolumn{3}{|c|}{ Total } & 2,842 & 500,552 & $1,470,600$ \\
\hline
\end{tabular}

indicate a large rock slide located at $28.079^{\circ} \mathrm{N}, 85.194^{\circ} \mathrm{W}$. It occurred at the lower part of the slope and blocked the valley. However, they did not create a lake because of the small area of the catchment upstream. The red dotted arrows show a shallow, disrupted landslide originated from a ridge (located at $28.08^{\circ} \mathrm{N}, 85.208^{\circ} \mathrm{W}$ ). Most of the landslides shown in Fig. 6a are distributed along the rivers, likely associated with river incision or loose deluvium with high landslide susceptibility.

\section{Landslide damage to the two roads}

The Pasang Lhamu Highway and Araniko Highway are two most important roads connecting Nepal and China. The Araniko Highway links Kathmandu, Nepal and Nielamu County, China. In this study, the section of the Araniko Highway between the place $\left(27.987262^{\circ} \mathrm{N}\right.$, $\left.85.982552^{\circ} \mathrm{E}\right)$ nearby Zhangmu Port and the location $\left(27.678835^{\circ} \mathrm{N}, 85.349647^{\circ} \mathrm{E}\right)$ southeast to Kathmandu was selected as the target to investigate the damage of coseismic landslides on the road. This section of Araniko Highway is about $117.3 \mathrm{~km}$ long. Based on visual interpretation of high-resolution satellite images and field investigations, we delineated 35 coseismic landslides damaging the Araniko Highway at 36 places. The longest section of the road damaged is about $156 \mathrm{~m}$ long which was buried by a landslide at $27.91744^{\circ} \mathrm{N}, 85.93064^{\circ} \mathrm{E}$. Considering the previous correlations between area and volume of individual landslides (Larsen et al. 2010; Xu et al. 2016b) and field investigations, the total volume of the 35 coseismic landslides was estimated to be about 0.37 million $\mathrm{m}^{3}$. Figure 7 shows the Araniko Highway damaged by coseismic landslides on satellite images at four places. Table 1 lists the detailed information on the 35 coseismic landslides and hazards on the road they caused.

The Pasang Lhamu Highway connects Kathmandu, Nepal and Gyirong County. The length of the section between the point $\left(27.735268^{\circ} \mathrm{N}, 85.305939^{\circ} \mathrm{E}\right)$ northwest to Kathmandu and the point $\left(28.278972^{\circ} \mathrm{N}, 85.377904^{\circ} \mathrm{E}\right)$ China-Nepal border is about $139.3 \mathrm{~km}$. Visual interpretation of satellite images and field investigations allowed us to delineate 89 coseismic landslides that damaged the

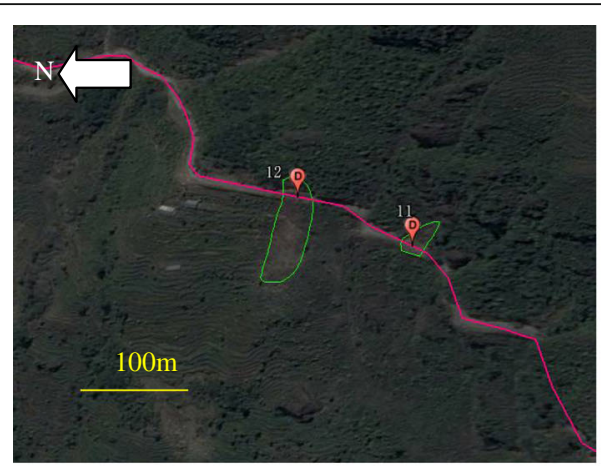

(a)

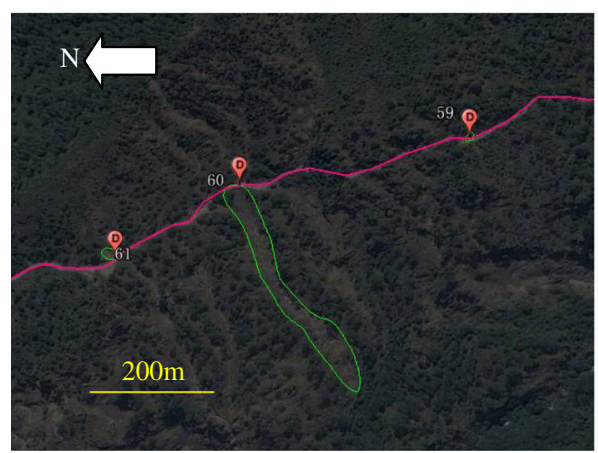

(c)

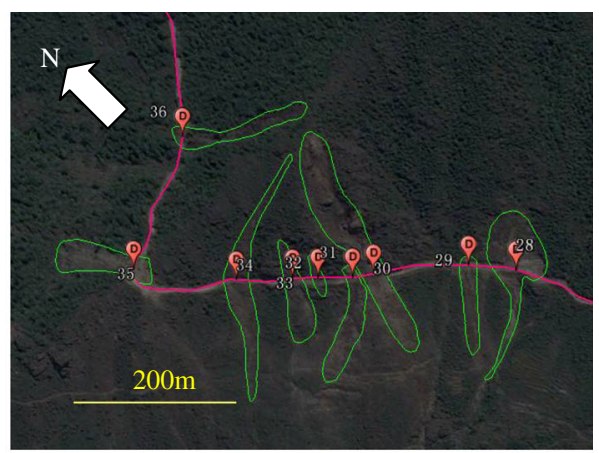

(b)

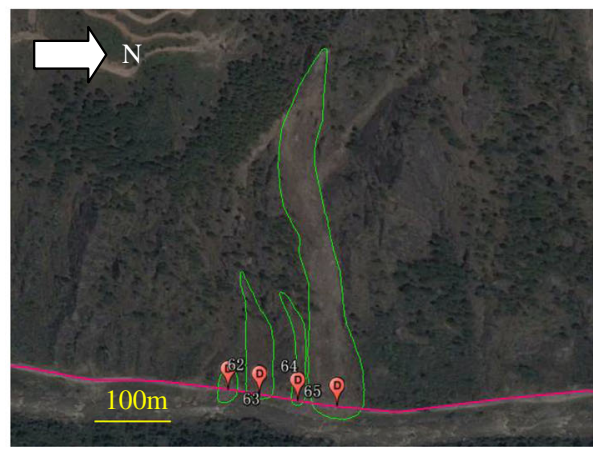

(d)

Fig. 8 Damaged sites along Pasang Lhamu Highway by coseismic landslides on satellite images. The detailed information of the landslides and associated damages on the road is listed in Table 2. a the No. 11 and 12 landslides, (b) the No. 28 36 landslides, (c) the No. 59, 60, and 61 landslides, (d) the No. 62, 63, 64, and 65 landslides along Pasang Lhamu Highway. All the satellite images were acquired on 3 May, 2015 

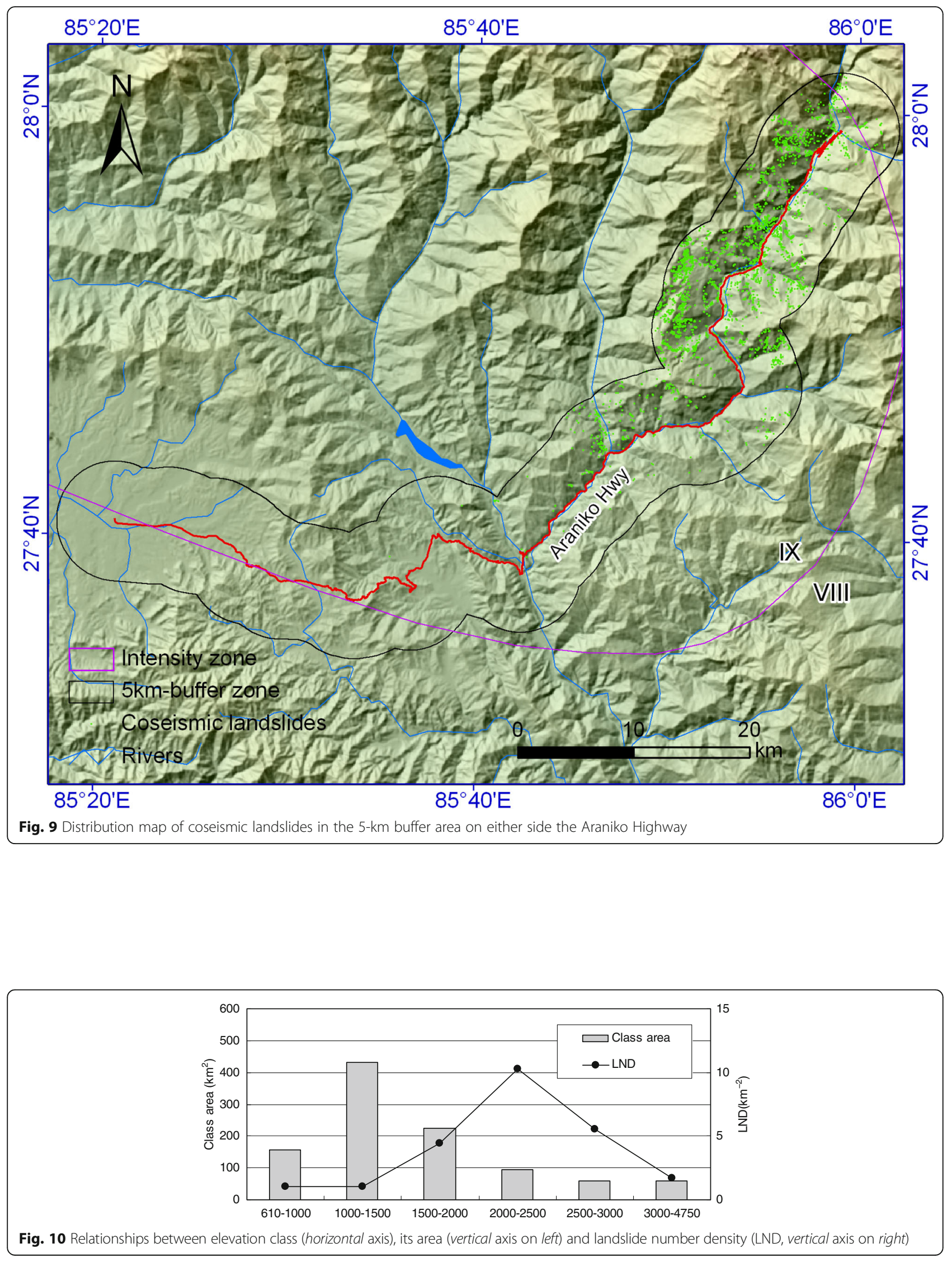


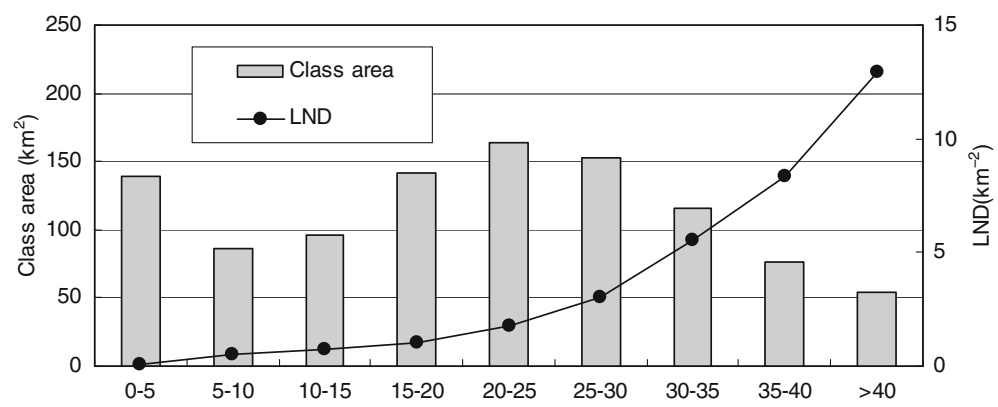

Fig. 11 Same as Fig. 10 but for slope angle (horizontal axis, unit: degree)

Pasang Lhamu Highway. The total length of damaged or buried roads is about 2,842 m, of which the longest section is about $209 \mathrm{~m}$ long, caused by a landslide located at $27.91744^{\circ} \mathrm{N}, 85.93064^{\circ} \mathrm{E}$. The total volume of the 89 landslides was estimated to be 1.47 million $\mathrm{m}^{3}$. Figure 8 shows satellite images of coseismic landslides along the Pasang Lhamu Highway. Table 2 shows the detailed information on the 89 coseismic landslides and their hazards on the road.

\section{Landslide inventory along the Araniko highway}

On either side of the $117.3 \mathrm{~km}$-long Araniko Highway, we constructed a $5-\mathrm{km}$ buffer region to construct a detailed and complete point-based coseismic landslide inventory. The area of this buffer region is $1,027.4 \mathrm{~km}^{2}$. Individual coseismic landslides were mapped as points at the central of the landslide. Consequently, we mapped 3,005 coseismic landslides in the area (Fig. 9), and calculated the landslide number density to be $3,005 / 1,027.4 \mathrm{~km}^{2}=2.925 \mathrm{~km}^{-2}$. The spatial distribution of the coseismic landslides along the Araniko Highway is quite uneven. Most of the landslides occurred in the mountainous areas to the north, where the landslide inventory is complete and detailed, i.e. small landslides are included. The buffer area only accounts for less $10 \%$ than the primary affected area of the main shock. The buffer area is approximately normal to the strike of the seismogenic structure (EW trending). Usually the seismic landslide density along the causative fault is uniform.
Therefore, we estimated the Gorkha quake triggered at least 30,000 landslides. Several other teams have released coseismic landslides related to the Gorkha quake. For example, Kargel (Kargel et al. 2016) only mapped 4,312 coseismic and postseismic landslides. A team from British Geological Survey et al. (British Geological Survey et al. 2015) identified about 5,600 coseismic landslides as polylines marking the location and movement path from head to toe of a landslide. Therefore, there might be false negative errors (omissions) in these released inventories of landslides triggered by the Gorkha quake.

\section{Spatial distribution of landslides along the Araniko highway}

As a common index to reflect landslide abundance, landslide number density was employed as the index to measure spatial distribution of the 3,005 landslides in the $5-\mathrm{km}$ buffer area of the Araniko Highway. In this study, five controlling factors including elevation, slope angle, slope aspect, lithology, and seismic intensity were selected to analyze their correlations with the landslides (Figs. 10, 11, 12, 13 and 14). The DEM of the area was derived from SRTM in 3 arc-second, which permitted to determine the elevations of the buffer area vary from $610 \mathrm{~m}$ to $4,750 \mathrm{~m}$. The study area was divided into six classes based on $500 \mathrm{~m}$ of elevation intervals, i.e. 610 $1000 \mathrm{~m}, 1000-1500 \mathrm{~m}, 1500-2000 \mathrm{~m}, 2000-2500 \mathrm{~m}$, 2500-3000 m, and 3000-4750 m (Fig. 10). The

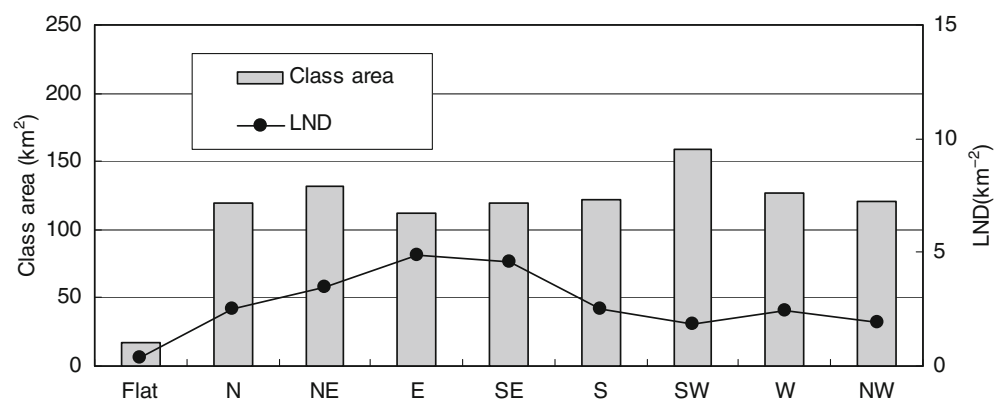

Fig. 12 Same as Fig. 10 but for slope aspects (horizontal axis) 


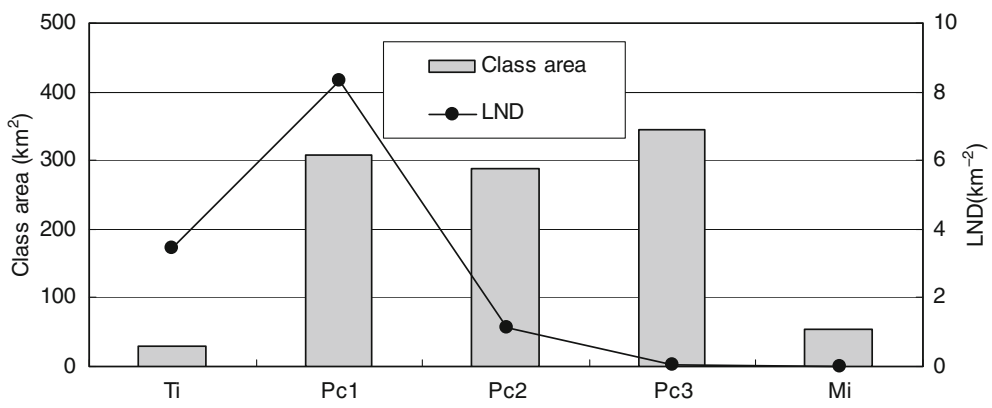

Fig. 13 Same as Fig. 10 but for lithology (horizontal axis)

elevations of most of the area $\left(814.97 \mathrm{~km}^{2}, 79.3 \%\right.$ of the total) are lower than $2,000 \mathrm{~m}$. The class $1000-1500 \mathrm{~m}$ occupies the largest area, which is $433 \mathrm{~km}^{2}$, accounting for $42.1 \%$ of the total. The class 2,000-2,500 m registered the largest LND value, which is $10.3 \mathrm{~km}^{-2}$. The landslide number density values gradually decrease at the elevations higher than 2,500 $\mathrm{m}$ and lower than 2,000 $\mathrm{m}$.

Slope angle is an important controlling factor of coseismic landslides. In this study, the slope angle of the buffer area ranges from $0^{\circ}$ to $74^{\circ}$, which was divided into 9 classes with an interval of $5^{\circ}$. Majority of the area (780.7 $\mathrm{km}^{2}, 76 \%$ of the total) has slope angles lower than $30^{\circ}$. As shown in Fig. 11, the landslide number density increases with the growing slope angle. The class $>40^{\circ}$ corresponds to the largest LND value, which is $12.92 \mathrm{~km}^{-2}$. In addition, the LND curve shows a concave form, implying the LND increases with the slope angle gradually. This suggests a very strong control of the slope angle on the coseismic landslides. Such a situation is also common in other earthquake events (Gorum et al. 2014; Xu et al. 2014; Xu et al. 2015; Tian et al. 2016).

Slope aspects (or facing directions) can affect the pattern of coseismic landslides because slopes with different aspects have varied responses to the movement directions of blocks or the propagating direction of seismic waves. The study area has nine classes of slope aspects, i.e. flat, north $(\mathrm{N})$, northeast $(\mathrm{NE})$, east $(\mathrm{E})$, southeast $(\mathrm{SE})$, south (S), southwest (SW), west (W), and northwest (NW). Fig. 12 shows the correlations between the slope aspect, area of its classes and landslide number density. It is clear that the slope aspects E and SE correspond to the two largest LND values, which are $4.87 \mathrm{~km}^{-2}$ and $4.58 \mathrm{~km}^{-2}$, respectively. This is perhaps related to the movement direction of the hanging wall of the seismogenic fault or the propagation direction of seismic wave (Shen et al. 2016). The study area is located east of the epicenter of the Gorkha main shock, and thus the propagating direction of seismic waves is eastward. During the Gorkha earthquake, the hanging wall of the fault, where the buffer area is located, moved toward south and probably generated inertia effect to the south. In addition, the slopes of southward aspect in the area are easily exposed to sunlight and rainfall, thus leading to widespread weathering layers and high susceptibility to seismic landslides.

The Gorkha earthquake affected area can be divided into a series of east-west trending major tectonic regions by three major active fault zones, including MFT, MBT, and MCT (Le Fort 1975; Nakata 1989; Upreti 1999; Wesnousky et al. 1999; Mukherjee 2015). Based on the geologic map of South Asia, the study area has five classes of lithology (rock types) generally from north to south, i.e. Tertiary igneous rocks (Ti), Precambrian rocks-1 (Pc1), Precambrian rocks-2 (Pc2), Precambrian rocks-3 (Pc3), and Mesozoic intrusive rocks (Mi). Figure 13 shows the correlations between lithology, its

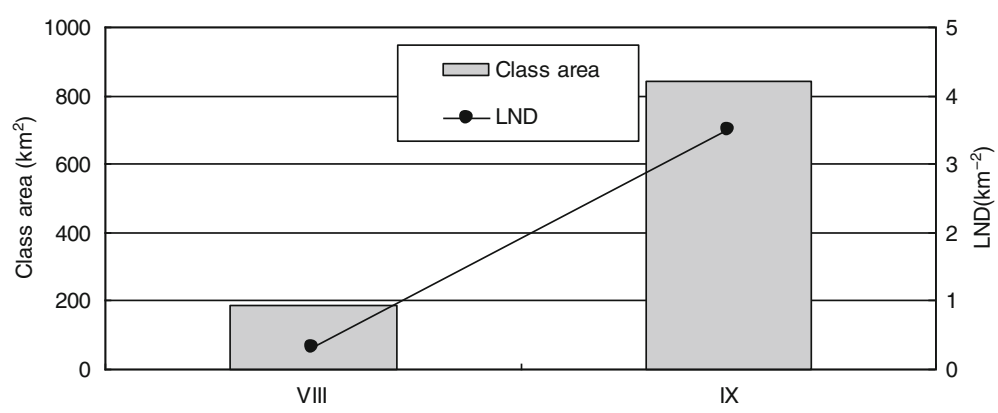

Fig. 14 Same as Fig. 10 but for seismic intensity (horizontal axis) 
class area and landslide number density. The three groups of Precambrian rocks cover most of the area, which is $942.8 \mathrm{~km}^{-2}$, occupying $91.8 \%$ of the total. The lithology class Pc1 registered the largest landslide number density, which is $8.32 \mathrm{~km}^{-2}$.

Seismic intensity and peak ground accumulation (PGA) are two common proxies representing the degree of seismic energy and often used to explore the effect of earthquakes on landslides. The PGA distribution map released by USGS (www.usgs.gov) is rather irregular in the $5-\mathrm{km}$ buffer area of the Araniko Highway because the buffer area is relatively small and there are perhaps significant errors generated by numerical simulation and limited stations. Therefore, we preferred to analyze the correlation between coseismic landslides and seismic intensity in this study. The seismic intensity map of the Gorkha earthquake was produced by China Earthquake Administration (CEA) (Fig. 1). Only VIII and IX intensity zones appear in the study area, which have the landslide number density values $0.32 \mathrm{~km}^{-2}$ and $3.5 \mathrm{~km}^{-2}$, respectively (Fig. 14). Despite merely two data points, these data show a positive correlation with the coseismic landslides, i.e. the place with larger seismic intensity has a higher landslide number density.

\section{Landslide hazard assessment}

In the aforementioned 5-km buffer area of the Araniko Highway, the WI vales were calculated to each class of all the five controlling factors, respectively. Then, the weighted thematic maps of the five factors were produced and were superposed to derive a landslide hazard index (LHI) map:

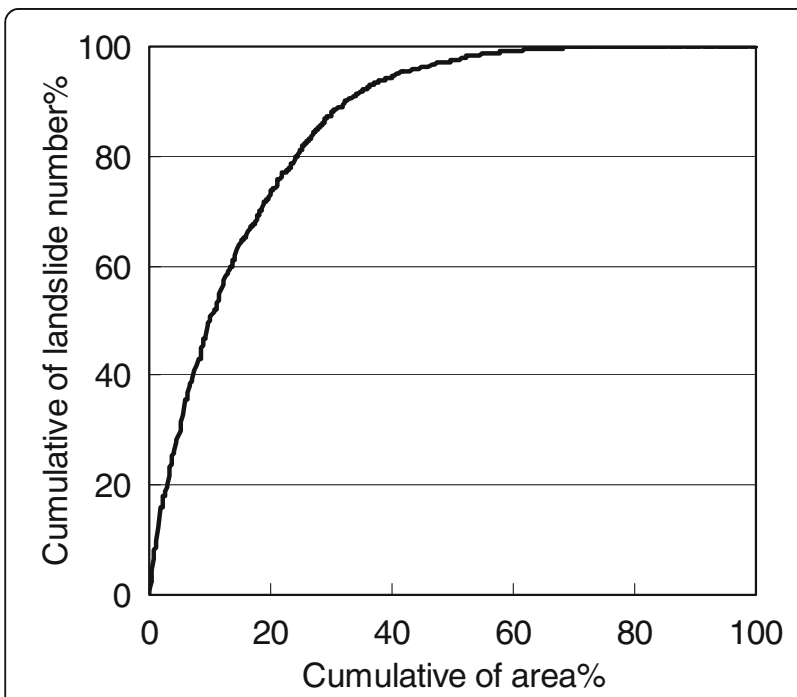

Fig. 15 The area under the curve representing the success ratio of the landslide hazard assessment. Area \% means the percentage of area to the study area for each factor class. Landslide number \% means the percentage of landslide number in a factor class to the total landslide number

$$
\begin{aligned}
\mathrm{LHI}= & \mathrm{WI}_{\text {Elevation }}+\mathrm{WI}_{\text {Slope angle }}+\mathrm{WI} \mathrm{I}_{\text {Slope aspect }} \\
& +\mathrm{WI}_{\text {Lithology }}+\mathrm{WI}_{\text {Seismic intensity }}
\end{aligned}
$$

The WI values indicate the relative importance of each factor to landslide hazard. Positive WI values mean the factor-class area is prone to coseismic landslides,

Table 3 Weight index values of various classes of five

\begin{tabular}{|c|c|c|c|c|}
\hline Factor & Class area & Landslide number & LND & WI \\
\hline \multicolumn{5}{|l|}{ Elevation } \\
\hline 610-1000 m & 155.94 & 159 & 1.02 & -1.05 \\
\hline $1000-1500 \mathrm{~m}$ & 433 & 438 & 1.01 & -1.06 \\
\hline $1500-2000 \mathrm{~m}$ & 226.03 & 1000 & 4.42 & 0.41 \\
\hline $2000-2500 \mathrm{~m}$ & 95.24 & 981 & 10.3 & 1.26 \\
\hline 2500-3000 m & 58.83 & 327 & 5.56 & 0.64 \\
\hline $3000-4750 \mathrm{~m}$ & 58.39 & 100 & 1.71 & -0.54 \\
\hline \multicolumn{5}{|l|}{ Slope angle } \\
\hline $0-5^{\circ}$ & 139.07 & 15 & 0.11 & -3.3 \\
\hline $5-10^{\circ}$ & 86.75 & 42 & 0.48 & -1.8 \\
\hline $10-15^{\circ}$ & 96.61 & 71 & 0.73 & -1.38 \\
\hline $15-20^{\circ}$ & 141.86 & 144 & 1.02 & -1.06 \\
\hline $20-25^{\circ}$ & 163.49 & 290 & 1.77 & -0.5 \\
\hline $25-30^{\circ}$ & 152.92 & 458 & 3.00 & 0.02 \\
\hline $30-35^{\circ}$ & 115.59 & 641 & 5.55 & 0.64 \\
\hline $35-40^{\circ}$ & 76.65 & 640 & 8.35 & 1.05 \\
\hline $40-74^{\circ}$ & 54.5 & 704 & 12.92 & 1.49 \\
\hline \multicolumn{5}{|l|}{ Slope aspect } \\
\hline Flat & 16.63 & 6 & 0.36 & -2.09 \\
\hline N & 120.07 & 300 & 2.50 & -0.16 \\
\hline $\mathrm{NE}$ & 131.27 & 459 & 3.50 & 0.18 \\
\hline E & 112.63 & 549 & 4.87 & 0.51 \\
\hline SE & 119.02 & 545 & 4.58 & 0.45 \\
\hline S & 121.36 & 305 & 2.51 & -0.15 \\
\hline SW & 158.51 & 295 & 1.86 & -0.45 \\
\hline W & 127.22 & 312 & 2.45 & -0.18 \\
\hline NW & 120.72 & 234 & 1.94 & -0.41 \\
\hline \multicolumn{5}{|l|}{ Lithology } \\
\hline $\mathrm{Ti}$ & 29.34 & 101 & 3.44 & 0.16 \\
\hline PC1 & 308.10 & 2564 & 8.32 & 1.05 \\
\hline $\mathrm{PC2}$ & 288.82 & 324 & 1.12 & -0.96 \\
\hline Pc3 & 345.91 & 16 & 0.05 & -4.15 \\
\hline $\mathrm{Mi}$ & 55.26 & 0 & 0 & -14.89 \\
\hline \multicolumn{5}{|l|}{ Seismic intensity } \\
\hline VIII & 185.60 & 60 & 0.32 & -2.2 \\
\hline IX & 841.84 & 2945 & 3.5 & 0.18 \\
\hline
\end{tabular}
controlling factors

Lithology type Mi registered no landslide. In order to avoid $\ln (0)$ in calculating WI value, we assigned the LND value of the class Mi with 0.000001 , i.e. a small enough value, and the WI value of the class is -14.89 
whereas negative WI values represent the opposite. WI values close to zero mean moderate probabilities of occurrence of coseismic landslides. Results show the LHI of the area is in the range from -23.546 to 4.48 . In order to examine the validity of the model, the 3,005 coseismic landslides aforementioned were employed to compare the known landslides with the landslide hazard index map. By referring to a common method, the regional area was categorized into 100 classes with a same area by the LHI value and the percentages of landslide number in each class were calculated. Then, a correlation curve between cumulative area percentages and cumulative percentage of landslide number from high to low LHI in a descending order was drawn (Fig. 15). It shows the area under the curve (AUC) is as much as $85.9 \%$, i.e. a quite satisfactory success ratio. The curve also reveals that $10 \%$ of the area with the highest landslide hazard index could cover 1,514 landslides, about $50.4 \%$ of the total. Likewise, 20 and $30 \%$ of the area with the highest landslide hazard index can account for 2,207 and 2,645 landslides, about 73.4 and $88 \%$ of the total, respectively.

We applied the WI values in Table 3 to a larger area, i.e. the rectangle in Fig. 1, to construct a landslide hazards map. For the areas with factor-attribute values beyond the ranges of the $5-\mathrm{km}$ buffer area, they are classified into the classes that are closest to them. The elevation ranges from $291 \mathrm{~m}$ to $7968 \mathrm{~m}$ in the area. The area with elevation less than $610 \mathrm{~m}$ was classified into the class $610-1000 \mathrm{~m}$ and the area with elevation higher than $4,750 \mathrm{~m}$ was classified into the class $3000-4750 \mathrm{~m}$. The range of slope angle of the rectangle area is $0-81.7^{\circ}$, therefore, the range of $74^{\circ}-81.7^{\circ}$ was merged into the

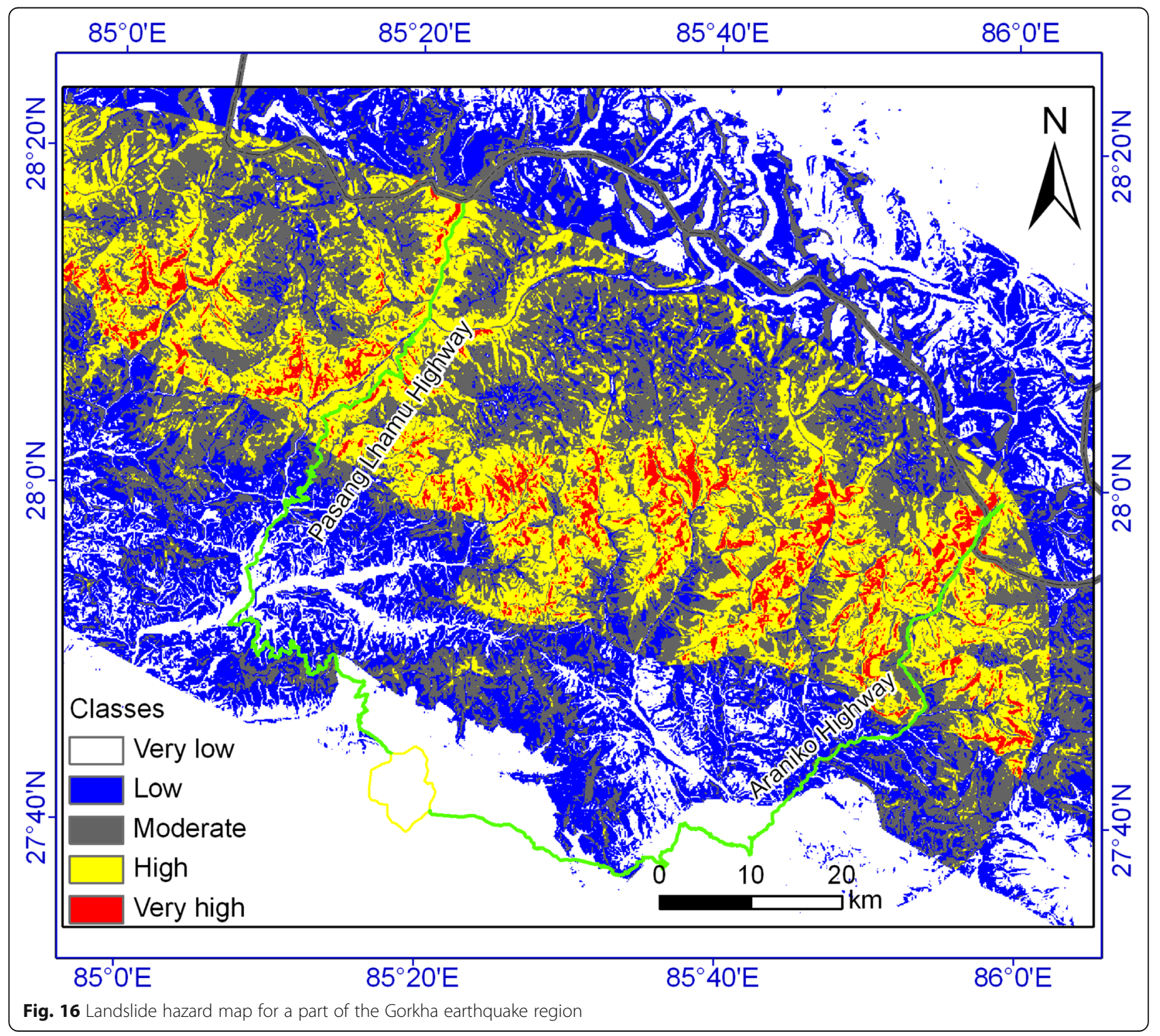


class $40-74^{\circ}$. The northern part of the rectangle area outcrop several other lithology types, such as Quaternary perennial ice and snow, Quaternary sediments, Neogene granite, Triassic metamorphic and sedimentary rocks, and Cretaceous sedimentary rocks. The northern rock group located at the northern part of the study area was not subdivided further because of limited geologic information there. The WI values of these lithology types were assigned the values same as the type Tertiary igneous rocks $(\mathrm{Ti})$. The rectangle area includes three seismic intensity zones, i.e. VII, VIII, and IX (Fig. 1). The seismic intensity VII is out of the range of the $5-\mathrm{km}$ buffer area and its WI value was calculated by linear extrapolation, which is -4.58. Subsequently, we constructed the LHI map of the rectangle area. We divided the map into four classes, i.e. very low, low, high, and very high, based on three breakpoints of the index values, i.e. $-3,-1,1$, and 3 . Figure 16 shows the derived landslide hazard map of the study area. The high zone and very high zone show a NWW-SEE directed distribution, which is coincident with the seismogenic fault and earthquake damage area. Figure 17 shows a three-dimensional view on the landslide hazard map. We overlaid the hazard map with 50\% transparency on satellite images of the Google Earth platform. However, several limitations of this result should be noted, including (1) Only five common factors were considered, while there should more factors can affect the occurrence of the coseismic landslides, such as rivers and seismogenic fault. (2) The weight value method is a bivariate method, interactions among factors cannot be considered; and (3) WI values were calculated based on the 3,005 landslides in the $5-\mathrm{km}$ buffer area along the Araniko Highway. Of course, it is inferior to use of a complete inventory of landslides throughout the earthquake-affected area. These limitations are expected to be improved in future research.

\section{Conclusions}

Based on high-resolution satellite images, field investigation, and GIS technology, we examined the coseismic landslides of the 2015 Gorhka, Nelpal earthquake that blocked or damaged the Araniko Highway $(117.3 \mathrm{~km})$ and Pasang Lhamu Highway $(139.3 \mathrm{~km})$ in Nepal. Results show 35 coseismic landslides damaged the Araniko Highway with a total length of the sections of the damaged road about $1,415 \mathrm{~m}$. The total volume of these 35 coseismic landslides was estimated to be about 0.37 million $\mathrm{m}^{3}$. We delineated 89 coseismic landslides that damaged the Pasang Lhamu Highway. The total length of the damaged or buried roads is about $2,842 \mathrm{~m}$. The total volume of these 89 landslides was estimated to be 1.47 million $\mathrm{m}^{3}$. In the $5-\mathrm{km}$ buffer area on either side of the Araniko Highway, we mapped 3,005 landslides caused by the Gorkha earthquake. The landslide number density of the buffer area is $2.925 \mathrm{~km}^{-2}$. Correlations between the landslides and five controlling factors were

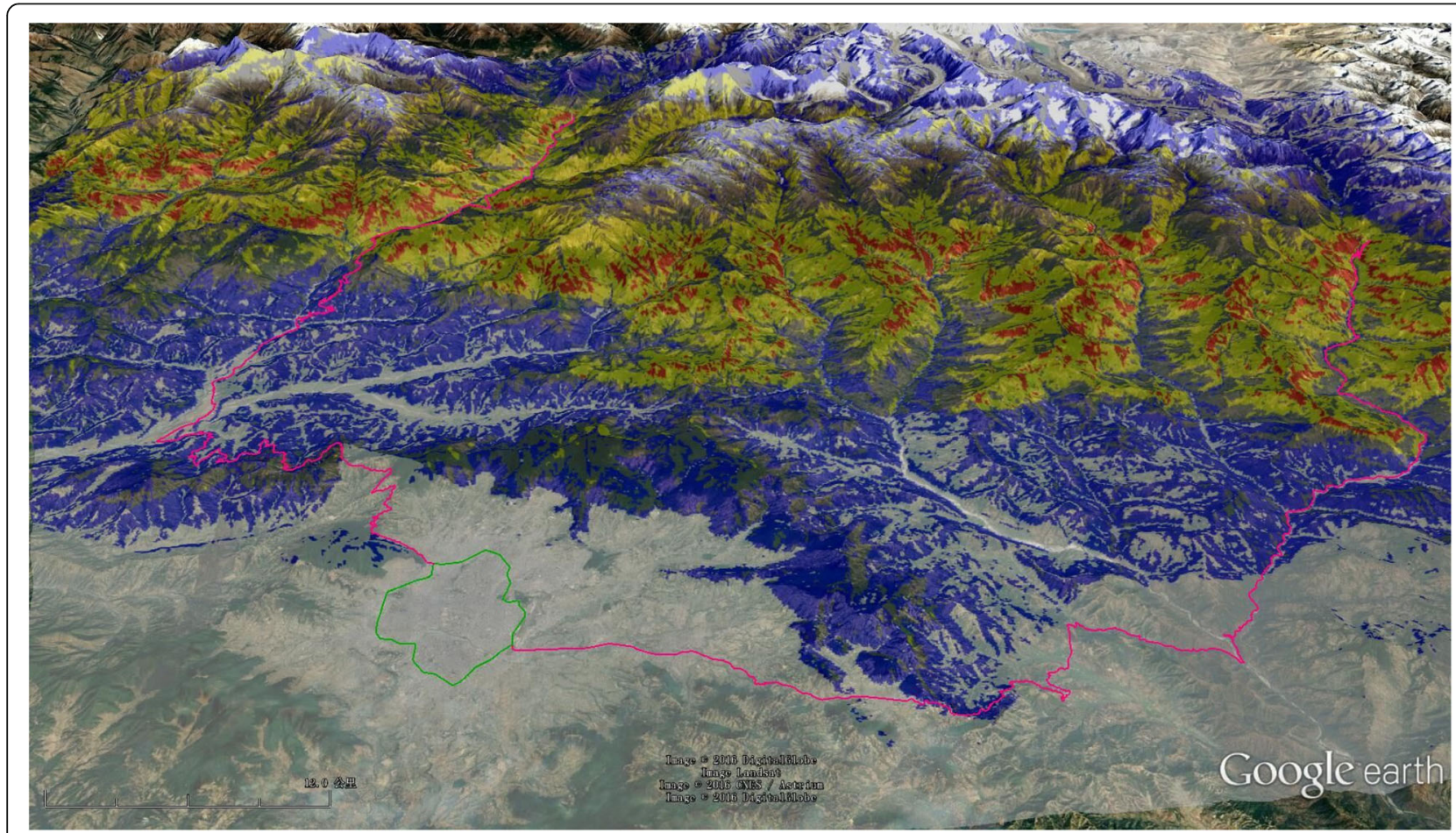

Fig. 17 A printing screen showing a three-dimensional perspective on the landslide hazard map. View to north 
analyzed based on the bivariate method. The results show the elevation class 2,000-2,500 $\mathrm{m}$ has the highest landslide concentration. The landslide number density value increases with the slope angle. The slope aspects $\mathrm{E}$ and SE correspond to the highest concentrations of coseismic landslides. The underlying bedrock of Precambrian rocks-1 (Pc1) registered the largest landslide number density. The area with seismic intensity IX has a much higher LND value than the area of the intensity VIII. We used the weigh index method to perform landslide hazard assessment in the $5-\mathrm{km}$ buffer area. Result shows the success ratio as high as $85.9 \%$. In addition, we prepared a landslide hazard assessment map for a larger area encompassing Rasuwa and Sindhupalchok counties of Nepal. It indicates the areas most likely to be prone to coseismic landslides, which would be helpful for constructing a more detailed and complete coseismic landslide inventory map throughout the earthquake-affected area subsequently. The result is also helpful predict the locations of landslides triggered by subsequent events, e.g. strong aftershocks and rainfalls, which would be a scientific reference for restoration, reconstruction, and landslide reduction and mitigation in the Gorkha earthquakeaffected area.

\section{Acknowledgments}

This research was supported by the National Natural Science Foundation of China $(41661144037,41472202,41472264)$ and the Special Project for China Earthquake Research (201508024). We are very grateful to the comments of two anonymous reviewers and the help of Ranjan Kumar Dahal (Editor).

\section{Competing interests}

The authors declare that they have no competing interests.

\section{Authors' contributions}

CX and YT mapped landslides on GE images. CX and GL participated the field investigations. CX, BZ, and $\mathrm{HR}$ provided the regional geologic and tectonic data. CX drafted the manuscript. All the authors reviewed and approved the manuscript.

\section{Publisher's Note}

Springer Nature remains neutral with regard to jurisdictional claims in published maps and institutional affiliations.

\section{Author details}

'Key Laboratory of Active Tectonics and Volcano, Institute of Geology, China Earthquake Administration, 1\# Huayanli, Chaoyang District, PO Box 9803, Beijing 100029, China. ${ }^{2}$ CCCC Highway Consultants Co., Ltd., Beijing 100088, China.

Received: 9 August 2016 Accepted: 30 March 2017

Published online: 05 April 2017

\section{References}

Angster, S., E.J. Fielding, S. Wesnousky, I. Pierce, D. Chamlagain, D. Gautam, B.N. Upreti, Y. Kumahara, and T. Nakata. 2015. Field reconnaissance after the 25 April 2015 M 7.8 Gorkha earthquake. Seismological Research Letters 86(6): 1506-1513. doi:10.1785/0220150135.

Avouac, J.-P., L. Meng, S. Wei, T. Wang, and J.-P. Ampuero. 2015. Lower edge of locked main Himalayan Thrust unzipped by the 2015 Gorkha earthquake. Nature Geoscience 8: 701-711. doi:10.1038/ngeo2518.
British Geological Survey, Earthquakes without Frontiers, Durham University. 2015. 2015 Nepal Earthquakes mapped landslide intensity (Revision 4.0 - 19 June 2015). https://data.hdx.rwlabs.org/group/nepal-earthquake.

Collins, B.D., and R.W. Jibson. 2015. Assessment of existing and potential landslide hazards resulting from the April 25, 2015 Gorkha, Nepal earthquake sequence. US Geological Survey.. https://pubs.er.usgs.gov/publication/ofr20151142. doi:10.3133/ofr20151142.

Dahal, R.K. 2016. Initiatives for rockfall hazard mitigation in Nepal. Bulletin of Nepal Geological Society 33: 51-56.

Duputel, Z., J. Vergne, L. Rivera, G. Wittlinger, V. Farra, and G. Hetényi. 2016. The 2015 Gorkha earthquake: a large event illuminating the main Himalayan thrust fault. Geophysical Research Letters 43(6): 2517-2525. doi:10.1002/ 2016GL068083.

Elliott, J.R., R. Jolivet, P.J. González, J.P. Avouac, J. Hollingsworth, M.P. Searle, and V.L. Stevens. 2016. Himalayan megathrust geometry and relation to topography revealed by the Gorkha earthquake. Nature Geoscience 9: 174180. doi:10.1038/ngeo2623.

Feng, H., A. Zhou, J. Yu, X. Tang, J. Zheng, X. Chen, and S. You. 2016. A comparative study on plum-rain-triggered landslide susceptibility assessment models in West Zhejiang Province. Earth Science 41(3): 403-415.

Gnyawali, K.R., S. Maka, B.R. Adhikari, D. Chamlagain, S. Duwal, and A.R. Dhungana. 2016. Spatial implications of earthquake induced landslides triggered by the April 25 Gorkha earthquake Mw 7.8: preliminary analysis and findings. In International conference on earthquake engineering and post disastor reconstruction planning 24 - 26 April, 2016, Bhaktapur, Nepal, 50-58.

Gorum, T., O. Korup, C.J. van Westen, M. van der Meijde, C. Xu, and F.D. van der Meer. 2014. Why so few? Landslides triggered by the 2002 Denali earthquake, Alaska. Quaternary Science Reviews 95: 80-94. doi:10.1016/j. quascirev.2014.04.032.

Hashash, Y.M.A., B. Tiwari, R.E.S. Moss, D. Asimaki, K.B. Clahan, D.S. Kieffer, D.S. Dreger, A. Macdonald, C.M. Madugo, H.B. Mason, M. Pehlivan, D. Rayamajhi, I. Acharya, and B. Adhikari. 2015. Geotechnical field reconnaissance: Gorkha (Nepal) earthquake of April 25, 2015 and related shaking sequence. In Geotechnical extreme event reconnaisance GEER association report No. GEER040.. https://works.bepress.com/rmoss/47: 250 pages.

Kargel JS, Leonard GJ, Shugar DH, Haritashya UK, Bevington A, Fielding EJ, Fujita K, Geertsema M, Miles ES, Steiner J, Anderson E, Bajracharya S, Bawden GW, Breashears DF, Byers A, Collins B, Dhital MR, Donnellan A, Evans TL, Geai ML, Glasscoe MT, Green D, Gurung DR, Heijenk R, Hilborn A, Hudnut K, Huyck C, Immerzeel WW, Jiang L, Jibson R, Kääb A, Khanal NR, Kirschbaum D, Kraaijenbrink PDA, Lamsal D, Liu S, Lv M, McKinney D, Nahirnick NK, Nan Z, Ojha S, Olsenholler J, Painter TH, Pleasants M, Pratima KC, Qi Y, Raup BH, Regmi D, Rounce DR, Sakai A, Shangguan D, Shea JM, Shrestha AB, Shukla A, Stumm D, van der Kooij M, Voss K, Wang X, Weihs B, Wolfe D, Wu L, Yao X, Yoder MR, Young N. 2016. Geomorphic and geologic controls of geohazards induced by Nepal's 2015 Gorkha earthquake. Science 351(6269): aac8353. doi:10.1126/science.aac8353

Koketsu, K., H. Miyake, Y. Guo, H. Kobayashi, T. Masuda, S. Davuluri, M. Bhattarai, L. B. Adhikari, and S.N. Sapkota. 2016. Widespread ground motion distribution caused by rupture directivity during the 2015 Gorkha, Nepal earthquake. Scientific Reports 6: 28536. doi:10.1038/srep28536.

Lacroix, P. 2016. Landslides triggered by the Gorkha earthquake in the Langtang valley, volumes and initiation processes. Earth, Planets and Space 68(1): 46. doi:10.1186/s40623-016-0423-3.

Larsen, I.J., D.R. Montgomery, and O. Korup. 2010. Landslide erosion controlled by hillslope material. Nature Geoscience 3(4): 247-251. doi:10.1038/ngeo776.

Le Fort, P. 1975. Himalayas: the collided range. Present knowledge of the continental arc. American Journal of Science 275-A: 1-44.

Lee, C.T., C.C. Huang, J.F. Lee, K.L. Pan, M.L. Lin, and J.J. Dong. 2008. Statistical approach to earthquake-induced landslide susceptibility. Engineering Geology 100(1-2): 43-58. doi:10.1016/j.enggeo.2008.03.004.

Martha TR, Roy P, Mazumdar R, Govindharaj KB, Kumar KV. 2016. Spatial characteristics of landslides triggered by the 2015 Mw 7.8 (Gorkha) and Mw 7.3 (Dolakha) earthquakes in Nepal. Landslides. doi:10.1007/s10346-016-0763-x

Moss, R.E.S., E.M. Thompson, D.S. Kieffer, B. Tiwari, Y.M.A. Hashash, I. Acharya, B.R. Adhikari, D. Asimaki, K.B. Clahan, and B.D. Collins. 2015. Geotechnical effects of the 2015 magnitude 7.8 Gorkha, Nepal, earthquake and aftershocks. Seismological Research Letters 86(6): 1514-1523. doi:10.1785/0220150158.

Mukherjee, S. 2015. A review on out-of-sequence deformation in the Himalaya. Geological Society, London, Special Publications 412(S): 67-109. doi:10.1144/SP412.13. 
Nakata, T. 1989. Active faults of the Himalaya of India and Nepal. Geological Society of America Special Papers 232: 243-264. doi:10.1130/SPE232-p243.

Parameswaran, R.M., T. Natarajan, K. Rajendran, C.P. Rajendran, R. Mallick, M. Wood, and H.C. Lekhak. 2015. Seismotectonics of the April-May 2015 Nepal earthquakes: An assessment based on the aftershock patterns, surface effects and deformational characteristics. Journal of Asian Earth Sciences 111: 161174. doi:10.1016/j.jseaes.2015.07.030.

Pathak, D. 2016. Knowledge based landslide susceptibility mapping in the Himalayas. Geoenvironmental Disasters 3(1): 8. doi:10.1186/s40677-016-0042-0.

Sarkar, S., D.P. Kanungo, A.K. Patra, and P. Kumar. 2008. GIS based spatial data analysis for landslide susceptibility mapping. Journal of Mountain Science 5(1): 52-62. doi:10.1007/s11629-008-0052-9.

Sharma, K., L. Deng, and C.C. Noguez. 2016. Field investigation on the performance of building structures during the April 25, 2015, Gorkha earthquake in Nepal. Engineering Structures 121: 61-74. doi:10.1016/j. engstruct.2016.04.043.

Shen, L., C. Xu, and L. Liu. 2016. Interaction among controlling factors for landslides triggered by the 2008 Wenchuan, China Mw 7.9 earthquake. Frontiers of Earth Science 10(2): 264-273. doi:10.1007/s11707-015-0517-4.

Sun, B., and P. Yan. 2015. Damage characteristics and seismic capacity of buildings during Nepal Ms 8.1 earthquake. Earthquake Engineering and Engineering Vibration 14(3): 571-578. doi:10.1007/s11803-015-0046-X.

Tian, Y., C. Xu, X. Xu, and J. Chen. 2016. Detailed inventory mapping and spatial analyses to landslides induced by the 2013 Ms 6.6 Minxian earthquake of China. Journal of Earth Science 27(6): 1016-1026. doi:10.1007/s12583-016-0905-z.

Tsangaratos, P., and I. Ilia. 2016. Comparison of a logistic regression and Naïve Bayes classifier in landslide susceptibility assessments: The influence of models complexity and training dataset size. Catena 145: 164-179. doi:10.1016/j.catena.2016.06.004

Upreti, B.N. 1999. An overview of the stratigraphy and tectonics of the Nepal Himalaya. Journal of Asian Earth Sciences 17(5-6): 577-606. doi:10.1016/S13679120(99)00047-4

Wang, K., and Y. Fialko. 2015. Slip model of the 2015 Mw 7.8 Gorkha (Nepal) earthquake from inversions of ALOS-2 and GPS data. Geophysical Research Letters 42(18): 7452-7458. doi:10.1002/2015GL065201.

Wang, F., M. Miyajima, R. Dahal, M. Timilsina, T. Li, M. Fujiu, Y. Kuwada, and Q. Zhao. 2016. Effects of topographic and geological features on building damage caused by 2015.4.25 Mw7.8 Gorkha earthquake in Nepal: a preliminary investigation report. Geoenvironmental Disasters 3(1): 7. doi:10.1186/s40677-016-0040-2.

Wesnousky, S.G., S. Kumar, R. Mohindra, and V. Thakur. 1999. Uplift and convergence along the Himalayan Frontal Thrust of India. Tectonics 18(6): 967-976. doi:10.1029/1999TC900026.

Xu, C. 2015. Preparation of earthquake-triggered landslide inventory maps using remote sensing and GIS technologies: principles and case studies. Geoscience Frontiers 6(6): 825-836. doi:10.1016/j.gsf.2014.03.004.

Xu, C., X. Xu, F. Dai, and A.K. Saraf. 2012. Comparison of different models for susceptibility mapping of earthquake triggered landslides related with the 2008 Wenchuan earthquake in China. Computers \& Geosciences 46: 317-329. doi:10.1016/j.cageo.2012.01.002.

Xu C, Xu X, Dai F, Wu Z, He H, Wu X, Xu S, Shi F. 2013a. Application of an incomplete landslide inventory, logistic regression model and its validation for landslide susceptibility mapping related to the May 12 , 2008 Wenchuan earthquake of China. Natural Hazards 68(2): 883-900. doi:10.1007/s11069-013-0661-7.

Xu C, Xu X, Yao Q, Wang Y. 2013b. GIS-based bivariate statistical modelling for earthquake-triggered landslides susceptibility mapping related to the 2008 Wenchuan earthquake, China. Quarterly Journal of Engineering Geology and Hydrogeology 46(2): 221-236. doi:10.1144/qjegh2012-006.

Xu, C., X. Xu, X. Yao, and F. Dai. 2014. Three (nearly) complete inventories of landslides triggered by the May 12, 2008 Wenchuan Mw 7.9 earthquake of China and their spatial distribution statistical analysis. Landslides 11(3): 441461. doi:10.1007/s10346-013-0404-6.

Xu, C., X. Xu, and J.B.H. Shyu. 2015. Database and spatial distribution of landslides triggered by the Lushan, China Mw 6.6 earthquake of 20 April 2013. Geomorphology 248: 77-92. doi:10.1016/j.geomorph.2015.07.002.

Xu C, Xu X, Tian Y, Shen L, Yao Q, Huang X, Ma J, Chen X, Ma S. 2016a. Two comparable earthquakes produced greatly different coseismic landslides: The 2015 Gorkha, Nepal and 2008 Wenchuan, China events. Journal of Earth Science 27(6): 1008-1015. doi:10.1007/s12583-016-0684-6.
Xu C, Xu X, Shen L, Yao Q, Tan X, Kang W, Ma S, Wu X, Cai J, Gao M, Li K. 2016b. Optimized volume models of earthquake-triggered landslides. Scientific Reports 6: 29797. doi:10.1038/srep29797.

Yalcin, A. 2008. GIS-based landslide susceptibility mapping using analytical hierarchy process and bivariate statistics in Ardesen (Turkey): Comparisons of results and confirmations. Catena 72(1): 1-12. doi:10.1016/j.catena.2007.01.003.

\section{Submit your manuscript to a SpringerOpen ${ }^{\circ}$ journal and benefit from:}

- Convenient online submission

- Rigorous peer review

- Immediate publication on acceptance

- Open access: articles freely available online

- High visibility within the field

- Retaining the copyright to your article

Submit your next manuscript at springeropen.com 